\title{
METODE PENGEPRESAN UNTUK MENINGKATKAN KUALITAS INDUSTRI PEMBUATAN TAHU DI KELURAHAN KEKALIK JAYA KOTA MATARAM
}

\author{
Asih Priyati ${ }^{1 *}$, Sirajuddin Haji Abdullah ${ }^{1}$, Surya Abdul Muttalib ${ }^{1}$, Agriananta Fahmi Hidayat $^{1}$, \\ Nanang Apriandi MS. ${ }^{1}$, Zulhan Widya Baskara ${ }^{1}$ \\ ${ }^{1}$ Program Studi Teknik Pertanian, Fakultas Tekologi Pangan dan Agroindustri, Universitas \\ Mataram, Jl.Majapahit No. 62, Mataram NTB \\ ${ }^{*}$ Korenpondensi: asihpriyati@unram.ac.id
}

Diterima 16 Desember 2019 / Disetujui 8 Januari 2020

\begin{abstract}
ABSTRAK
Kelurahan Kekalik Jaya adalah kawasan di Kota Mataram yang terdapat banyak industri rumah tangga pengrajin olahan kedelai berupa tahu. Berdasarkan hasil survei yang dilakukan oleh tim Kegiatan Pengabdian kepada Masyarakat, proses pengepresan sekaligus pencetakan tahu masih dilakukan secara manual yaitu meletakkan beban berat berupa beton cor di atas cetakan tahu. Proses pengepresan dengan cara tersebut kurang menjamin kualitas tahu yang dihasilkan karena tingkat kepadatan tahu yang dihasilkan tidak seragam serta memakan waktu lama. Dalam aspek keselamatan kerja, aktivitas pengrajin tahu dalam proses pengepresan secara manual termasuk tidak aman karena aktivitas memindahkan beban berat secara berulang-ulang dapat menimbulkan resiko cidera. Hasil diskusi tim penyuluh dengan pengrajin tahu menyimpulkan bahwa perlu dilakukan kegiatan penyuluhan dan praktek penggunaan metode pengepresan tahu dengan alat pres ulir. Program pemberdayaan masyarakat dilakukan dengan tujuan untuk meningkatkan kualitas proses pembuatan tahu pada industri tahu Kelurahan Kekalik Jaya Mataram. Penggunaan pres ulir dalam proses pencetakan tahu dapat meningkatkan kualitas tahu karena tahu hasil pengepresan memiliki tingkat kepadatan yang seragam, serta memakan waktu proses yang lebih singkat. Kegiatan dilakukan dengan metode penyuluhan dan praktek. Penyuluhan dilakukan oleh tim pengabdian kepada masyarakat dengan materi berupa 1) Kadar air pada tahu dan umur simpan; 2) Postur tubuh saat kerja yang aman secara ergonomika; 3) Prinsip kerja penekanan sistem ulir; dan 4) Petunjuk pengoperasian dan pemeliharaan alat pres ulir tahu. Hasil kegiatan meunjukkan bahwa pengrajin tahu telah mendapat wawasan dan ketrampilan tentang metode pengepresan tahu menggunakan alat pres ulir yang dapat mengatasi masalah keselamatan kerja, meringkas waktu proses pengepresan, serta meningkatkan kepadatan tahu yang dibuat.
\end{abstract}

Kata kunci: pres ulir, postur kerja, waktu proses, kepadatan tahu

\section{PENDAHULUAN}

Kelurahan Kekalik Jaya yang merupakan salah satu bagian Kota Mataram merupakan sentra pengrajin tahu dan tempe yang cukup besar di pulau Lombok. Dengan jumlah pengrajin yang banyak dan area pemasaran yang tidak terbatas di kota Mataram saja tapi juga ke Lombok Tengah, Lombok Barat dan 
Lombok Timur, menjadikan produk tempe tahu dari Kekalik ini cukup banyak dikenal masyarakat.

Tahu diproduksi dengan memanfaatkan sifat protein yaitu akan menggumpal bila bereaksi dengan asam (Suprapti, 2005). Penggumpalan protein akan berlangsung secara cepat dan serentak di seluruh bagian sari kedelai, sehingga sebagian besar air yang semula tercampur dalam sari kedelai akan terperangkap di dalamnya.

Untuk membuat sari kedelai, dalam proses menghancurkan biji kedelai sebagai bahan utama pembuatan tahu, mereka sudah menggunakan mesin penggiling dengan tenaga penggerak motor bakar. Perebusan bubur kedelai yang awalnya dulu mereka menggunakan perebusan secara langsung, sebagian besar mereka melakukan perebusan dengan menggunakan uap panas, sebagian pengrajin tahu sudah mendapatkan bantuan peralatan boiler dari pemerintah, dan sebagian membuat sendiri dengan memanfaatkan drum bekas.

Proses berikutnya setelah perebusan dan penyaringan sari kedelai, setelah dilakukan penggumpakan sari kedelai menggunakan air garam laut, salah satu tahapan yang tidak kalah pentingnya adalah proses pengepresan yang bertujuan untuk mengeluarkan air dari dalam tahu dan sekaligus memberi bentuk pada tahu.

Dari 5 lokasi pengrajin tahu yang disurvei, mereka semua melakukan pengepresan dengan menggunakan cara yang sama, yaitu bubur tahu yang sudah dituang di tempat cetakan beralaskan kain saring tahu, setelah ditutup dan diberi papan penutup kemudian ditindih dengan beban batu atau cor beton yang beratnya bervariasi antara $10-20 \mathrm{~kg}$ dengan jumlah antara 1-3buah. Pengepresan dengan cara seperti ini ada beberapa kelemahan, di antaranya adalah masalah keamanan dan keselamatan kerja. Dengan posisi pengepresan di atas meja kerja, kemudian untuk melakukan pengepresan harus mengangkat beban yang berat akan beresiko tinggi mengalami cidera otot punggung, pinggang dan tangan bagi pengrajin. Dalam jangka panjang juga dapat mengalami pegal-pegal pada lokasi yang menetap. Postur mengangkat dengan badan membungkuk, dan beban lebih dari $10 \mathrm{~kg}$ termasuk postur dan pembebanan yang perlu dilakukan perbaikan karena dalam jangka panjang dapat menimbulkan cidera (Rukmana, 2018).

Kelemahan yang lain adalah pengepresan membutuhkan waktu yang cukup lama tetapi tidak ada standar waktu. Yang dilakukan oleh pengrajin adalah dengan menggoyang-goyangkan beban batu untuk merasakan tingkat kepadatan tahu yang dibuat sehingga menimbulkan kemungkinan tidak seragamnya kepadatan tahu.

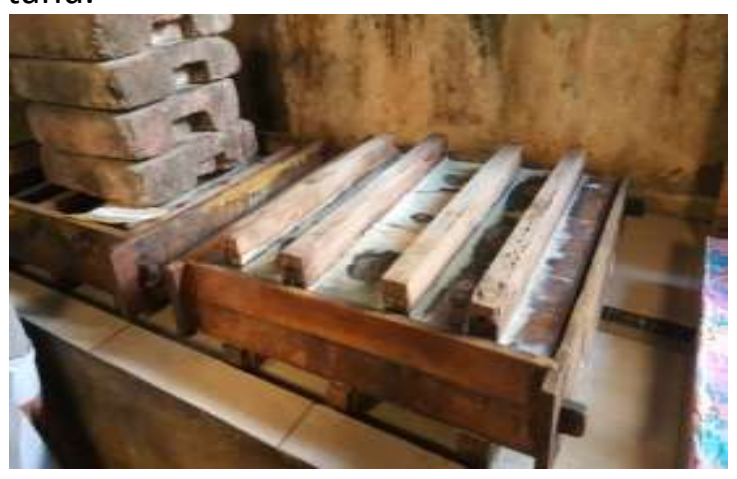

Gambar 1. Pengepresan tahu secara manual

Tahu yang dihasilkan oleh pengrajin tahu di Kekalik ini masih mengandung banyak kadar air. Mereka rata-rata membuat tahu pada siang hari sehari sebelum dijual. Supaya tahu tidak rusak dan untuk lebih memadatkan tekstur tahu, dan sekaligus menambahkan rasa asin, pengrajin tahu di Kekalik rata-rata melakukan perebusan kembali terhadap tahu yang sudah dipotong-potong. Perebusan kembali biasanya dilakukan sebanyak dua kali sampai menjelang dijual di pasar pada pagi hari. Tahu produksi 
industri dari Kekalik ini memiliki daya tahan tidak sampai 24 jam dalam suhu ruang. Jika dibiarkan begitu saja dalam waktu setengah hari maka akan mulai terasa lengket dan mulai rusak.

Menurut Suharto menurunkan kandungan air bahan pangan sehingga kurang/tidak memberi kesempatan untuk tumbuh /hidupnya mikroba dengan pengeringan/penguapan kandungan air yang ada di dalam maupun di permukaan bahan pangan, hingga mencapai kondisi tertentu adalah merupakan salah satu cara pengawetan bahan pangan di samping cara lain berupa menghambat enzim-enzim dan aktivitas/ pertumbuhan mikroba dengan menurunkan suhunya hingga dibawah $0^{\circ} \mathrm{C}$.

Kadar air bahan menunjukkan banyaknya kandungan air persatuan bobot bahan. Dalam hal ini terdapat dua metode untuk menentukan kadar aair bahan tersebut yaitu berdasarkan bobot kering (dry basis) dan berdasarkan bobot basah (wet basis). Dalam penentuan kadar air bahan hasil pertanian biasanya dilakukan berdasarkan obot basah. Dalam perhitungan ini berlaku rumus sebagai berikut: $\mathrm{KA}=(\mathrm{Wa} / \mathrm{Wb}) \times 100 \%$ (Taib dan Gunarif, 1988).

Berdasarkan kondisi proses pengepresan tahu yang dilakukan oleh pengrajin tahu di Kekalik, akan beresiko terhadap keamanan dan keselamatan operator, proses pengepresan tahu masih membutuhkan waktu yang lama, serta kadar air dalam tahu sangat tinggi sehingga umur simpannya rendah, menuntut adanya solusi untuk mengatasi hal tersebut. Dengan menggunakan alat pengepres tahu tenaga ulir yang dipakai dipakai dalam masalah proses pengepresan, diharapkan akan dapat mengatasi kendala-kendala tersebut di atas.

Belum pahamnya pengrajin tahu mengenai hubungan kandungan air dalam bahan pangan dengan umur simpannya juga dipandang perlu untuk dilakukan penyuluhan terkait supaya mereka paham. Oleh karena itu dalam kegiatan pengabdian kepada masyarakat ini dilakukan penyuluhan metode pengepresan tahu menggunakan alat pengepres ulir untuk meningkatkan kepadatan tahu dan sekaligus praktek mengggunakan alatnya. Demikian juga mengenai resiko cidera otot akibat mengangkat beban berat dengan postur posisi kerja yang kurang tepat, maka perlu dilakukan penyuluhan materi ini.

Kegiatan pengabdian kepada masyarakat pada pengrajin tahu Kelurahan Kekalik Jaya Kota Mataram dalam pelaksanaannya bertujuan memperbaiki kondisi proses pengepresan tahu yang akan berpengaruh terhadap kepadatan tahu dan mengurangi waktu pengepresan, memberikan penyuluhan mengenai postur tubuh posisi kerja yang tidak beresiko cidera otot dalam proses pengepresan, memperkenalkan dan mempraktekkan penggunaan alat pengepres tahu dengan sistem ulir, memberikan penyuluhan tentang keterkaitan kandungan air dalam bahan pangan terhadap umur simpannya.

Melalui kegiatan ini diharapkan pengrajin tahu di kelurahan Kekalik Jaya Mataram memiliki pengetahuan mengenai metode pengepresan tahu dengan alar ulir tekan dan mampu menggunakannya, dan untuk memperbaiki postur kerja serta memperpendek waktu pengepresan tahu.

$$
\text { Proses pengepresan dalam }
$$

pengolahan tahu bertujuan untuk memisahkan air yang diperoleh dari proses pengambilan sari kedelai setelah diblender. Pengolahan tahu yang dilakukan oleh pelaku industri tahu di kelurahan Kekalik Jaya Mataram telah dilakukan secara turun temurun.

Dalam proses pengepresan yang sekaligus bertujuan memberikan bentuk tahu ini sudah mereka lakukan secara turun temurun pula dengan cara menindihkan batu atau cor beton. Dengan cara seperti 
ini secara ergonomika akan menimbulkan resiko cidera atau pegal yang menetap pada operator. Selain itu proses pengepresan secara manual memakan waktu yang relatif lama yaitu sekitar 30 menit dengan tahu yang dihasilkan memiliki kandungan air yang masih tinggi dan kepadatannya rendah. Menurut Suprapti (2005) tingkat kepadatan merupakan salah satu hal yang mempengaruhi kualitas tahu.

Alat pengepres yang didesain untuk dikenalkan dalam kegiatan pengabdian kepada masyarakat ini menggunakan sistem ulir yaitu ulir sebagai lead screw (poros berulir). Lead screw adalah poros berulir yang merupakan pengubah gerakan dengan memanfaatkan gaya tekan akibat perputaran ulir menjadi gerakan linier (Pratomo, .......... Ulir dalam pemakaiannya selalu bekerja berpasangan antara ulir luar maupun ulir dalam. Gambar ulir dapat dilihat pada gambar berikut

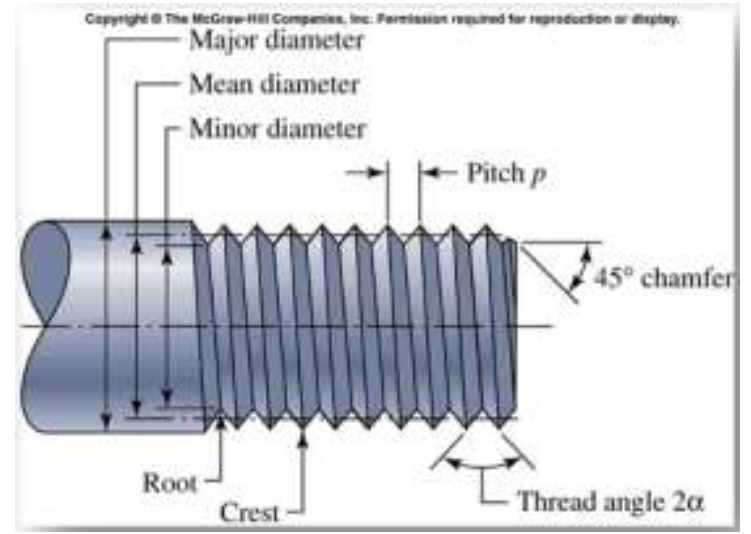

Gambar 2. Bagian ulir sebagai komponen penting dalam alat pres ulir tekan

Gaya tekan adalah gaya yang diberikan oleh bidan pada benda. Arah gaya tekan normal selalu tegak lurus terhadap bidang (baik bidang horizontal maupun bidang miring). Gaya tekan timbul akibat akibat dari gaya benda yang menekan bidang.

Alat pengepres tahu memiliki gaya vertikal. Gaya putar pada ulir mengakibatkan ulir bergerak secara vertikal sehingga menyebabkan timbulnya gaya tekan pada benda. Benda dalam hal ini adalah loyang tempat sari tahu dan bidang adalah papan yang digunakan untuk menekan sari tahu pada loyang. Secara sederhana dapat dijelaskan bahwa penekanan dengan sistem ulir ini seperti mur baut. Karena adanya ulir maka mur dapat bergerak pada baut. Begitu juga dengan alat pengepres tahu dengan memberika gaya putar searah atau berlawanan arah jam maka ulir bidang untuk menekan benda dapat bergerak secara vertikal atau naik turun.

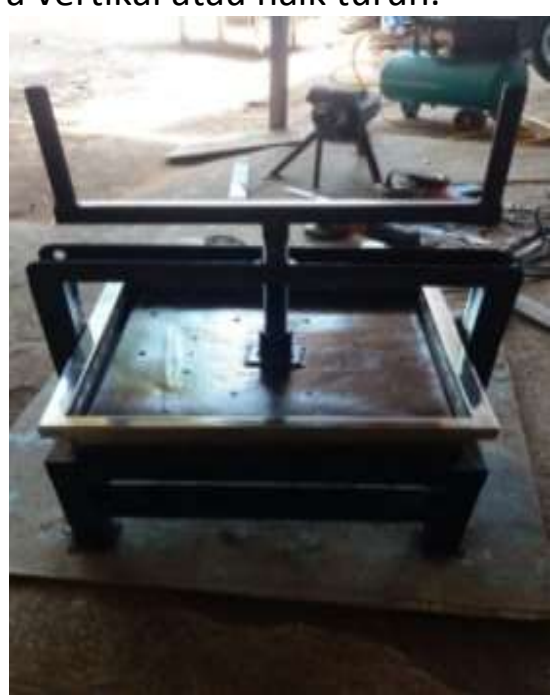

Gambar 3. Alat pres tahu sistem ulir tekan

Inti kegiatan ini adalah memanfaatkan alat pres ulir dalam proses pengepresan tahu, diawali dengan penyuluhan mengenai kandungan air dalam bahan pangan, postur kerja yang aman. Kemudian dilanjutkan dengan penyuluhan prosedur penggunaan dan perawatan alat pres ulir. Dan kegiatan terakhir adalah praktek pengoperasian alat dan evaluasi.

\section{METODE KEGIATAN}

\section{Realisasi Pemecahan Masalah}

Berdasarkan pada kerangka pemecahan masalah sebagaimana yang diuraikan sebelumnya, maka yang 
dilakukan adalah penyuluhan dan pelatihan teknis kepada khalayak sasaran strategis untuk merealisasikan kerangka pemecahan masalah yang ada, dengan memberikan beberapa materi yang sesuai dengan kebutuhan khalayak dan kemampuan tim penyuluh. Materi-materi penyuluhan yang diberikan dalam pengabdian kepada masyarakat adalah sebagai berikut: (1) Kadar air pada tahu dan umur simpan, (2) Postur tubuh saat kerja yang aman secara ergonomika (3) Prinsip kerja penekanan sistem ulir (4) Petunjuk pengoperasian dan pemeliharaan alat pres ulir tahu. Setelah penyuluhan, kegiatan dilanjutkan dengan praktek penggunaan alat pres tahu sistem ulir.

Sasaran kegiatan ini adalah pelaku industri pengrajin tahu di Gerisak kelurahan Kekalik Jaya Mataram yang tergabung dalam kelompok "Maju Bersama".

Kegiatan penyuluhan ini dilaksanakan di wilayah industri pengrajin tahu kelurahan Kekalik Jaya kota Mataram, pada tanggal 3 Nopember 2018 dengan pertimbangan bahwa lokasi ini merupakan salah satu daerah sebagai penghasil tahu dengan sebagian penduduknya berprofesi sebagai pengrajin tempe dan tahu yang masih perlu mendapatkan sentuhan teknologi berupa peralatan mekanis guna menggantikan cara-cara tradisional agar membantu memudahkan proses pengolahannya.

Sebelum kegiatan pengabdian, terlebih dahulu disiapkan alat pres ulir dengan membuat desain di Lab Daya dan Mesin Pertanian Fakultas Teknologi Pangan dan Agroindustri Universitas Mataram. Setelah itu dilanjutkan proses pengerjaan pembuatan alat pres ulir.

Penetapan waktu penyuluhan berdasarkan hasil pengamatan dan kunjungan pendahuluan yang akan dilakukan ke lokasi dan hasil diskusi dengan para pengrajin tahu, sehingga dengan demikian ditetapkan bahwa penyuluhan dilakukan pada waktu dan tempat yang disepakati bersama antara tim penyuluh dengan masyarakat pengrajin tahu.

\section{Rancangan Evaluasi}

Evalusi kegiatan ini dilakukan setelah penyampaian materi dan praktek. Evaluasi dilakukan dengan melihat tanggapan peserta dan kemampuan penguasaan materi yang telah diberikan. Tanggapan dan penguasaan materi diukur dengan memantau pertanyaan yang disampaikan peserta kepada penyaji materi, keaktifan peserta saat melakukan praktek dan kehadiran peserta, serta kemampuan peserta dalam menggunakan alat pres ulir.

\section{Penyampaian Materi Penyuluhan}

Pembukaan penyuluhan diawali dengan sambutan pengurus kelompok pengrajin tahu yaitu Bapak Bahriawan, kemudian dilanjutkan penyampaian materi tentang Kadar air pada tahu dan umur simpan.

Penyampaian materi dalam bentuk ceramah dan diskusi, sedangkan praktek pengoperasian alat langsung didemonstrasikan di tempat dengan bantuan peserta sehingga pertanyaan akan terjadi interaksi aktif antara tim penyuluh dan masyarakat peserta penyuluhan.

\section{HASIL DAN PEMBAHASAN}

Hasil pengabdian kepada masyarakat yang mengambil tema "Metode Pengepresan untuk Meningkatkan Kepadatan Tahu" ini dapat diketahui manfaatnya secara langsung maupun tidak langsung. Dari penyuluhan materi Kadar air pada tahu dan umur simpan yang disampaikan oleh pemateri, beberapa sasaran pengabdian kepada masyarakat menunjukkan respon bahwa mereka baru tahu kandungan air pada tahu berpengaruh terhadap umur simpan. 
Selama penyuluhan disampaikan, para peserta mendengarkan dengan seksama, munculnya banyak pertanyaan dari para peserta menunjukkan para peserta sangat antusias untuk memahami permasalahan yang ada. Pengrajin tahu lebih paham bahwa langkah yang dilakukan selama ini dengan melakukan perebusan ulang sebanyak dua kali dapat mencegah kerusakan tahu karena dengan merebus tahu sampai mendidih akan mencegah tumbuh dan berkembangnya bakteri yang dapat menyebabkan busuknya tahu.

Penyampaian materi berikutnya adalah materi tentang postur tubuh yang ergonomis. Pada pemaparan materi ini tanggapan pengrajin merasa sudah terbiasa bertahun-tahun dan turun temurun melakukan kegiatan pengepresan dengan cara manual maupun tahapan proses yang lain. Dari diskusi yang terjadi dapat disimpulkan bahwa pada umumnya pengrajin tahu kurang memahami bahwa postur kerja yang kurang sesuai dapat berakibat buruk dalam jangka panjang.

Pemaparan materi berikutnya adalah tentang prinsip kerja penekanan sistem ulir dan dilanjutkan dengan petunjuk pengoperasian dan pemeliharaan alatpre ulir. Dalam sesimateri ini peserta sangat antusias dan terlibat langsung karena pada sesi ini langsung menggunakan alat peraga dan alat yang akan digunakan untuk praktek.

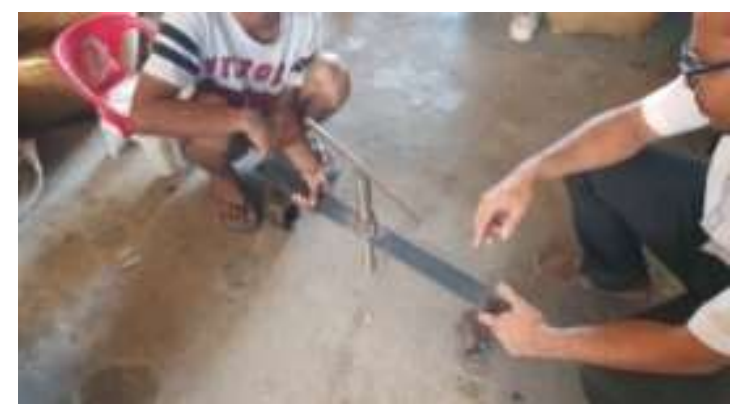

Gambar 5. Penjelasan prinsip ulir tekan dan penggunaan alat pres ulir tekan

Selama kegiatan pelatihan, penyuluh menyampaikan materi dengan bahasa yang komunikatif yang mudah difahami oleh peserta mengingat sebagian besar peserta memiliki pendidikan yang rendah. Peserta yang diberikan ilmu dan penerapan alat mekanik sangat senang dikarenakan telah terlihatnya manfaat dari penerapan alat baik dari segi efisiensi tenaga dan waktu pemanfaatannya.

Sesi penting berikutnya yang ditunggu dengan antusias oleh peserta adalah praktek pengepresan tahun dengan menggunakan alat pres ulir. Dalam sesi praktek ini bahan praktek berupa sari kedelai yang siap dicetak menjadi tahu diperoleh dari pengrajin dengan tahap penyiapan bahan seperti yang biasa mereka lakukan. Tahapan penyiapan bahan adalah dengan merendam kedelai yang sudah dicuci.

Setelah ditiriskan, kedelai dihancurkan dengan alat yang digerakkan dengan tenaga motor bakar. Pada tahap ini dilakukan penambahan air dengan tujuan agar kedelai lebih mudah diblender dan mudah dalam mengambil sarinya. Setelah kedelai sudah berbentuk menjadi bubur, proses selanjutnya adalah pemasakan bubur kedelai.

Pemasakan dilakukan tidak secara langsung di atas api melainkan dengan menggunakan sistem boiler, di mana pada boiler yang mendidihkan air menghasilkan uap panas yang dialirkan ke dalam ruang pemasakan bubur kedelai. Cara penggunaan boiler ini menghasilkan tahu yang tidak berbau asap dan tidak timbul kerak sehingga meminimalkan bahan yang terbuang.

Proses berikutnya adalah pengambilan sari kedelai, yaitu dilakukan dengan memisahkan cairan dari bubur kedelai yang sudah dimasak dari ampasnya. Bubur kedelai yang sudah masak dialirkan ke arang penyaring sari kedelai dan untuk meniriskan ampasnya dilakukan dengan mengepres menggunakan beban beton cor di atas kain 
yang berisi ampas kedelai. Cara pengepresan seperti ini juga dilakukan pada pengepresan tahu.

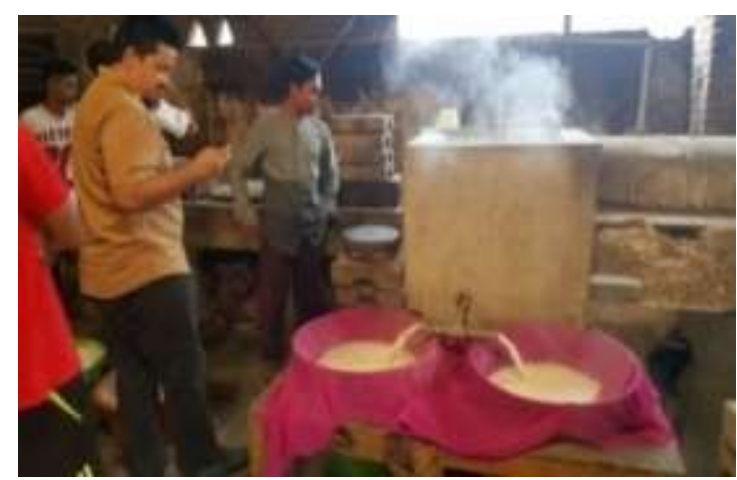

Gambar 6. Kedelai yang ditiriskan dan proses pemasakan bubur kedelai

Proses berikutnya adalah sari kedelai yang sudah ditampung dalam bak-bak besar diberikan larutan garam laut yang bertujuan untuk menggumpalkan protein pada sari kedelai yang akan dibuat menjadi tahu. Dalam tahap ini setelah diberikan larutan garam laut, bahan harus didiamkan dulu, sambil menunggu alat pres cetak siap digunakan. Dalam tahap ini terjadi pembuangan waktu karena proses pengepresan dan sekaligus pencetakan tahu memerlukan waktu tidak kurang dari 30 menit.

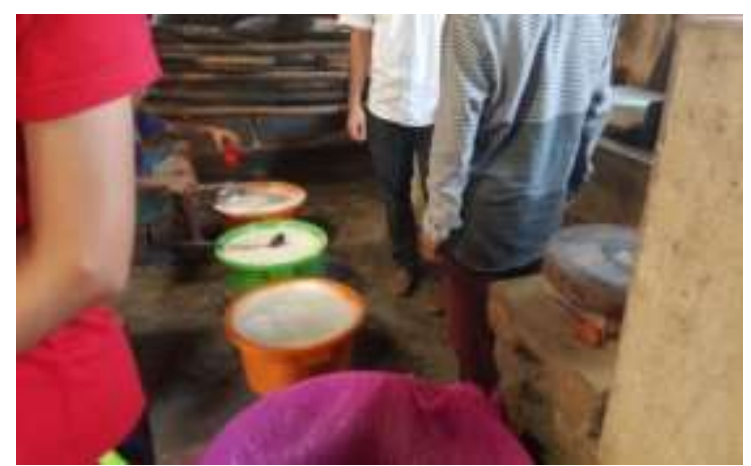

Gambar 7. Sari kedelai siap dipres dan dicetak menjadi tahu

Proses berikutnya adalah sesi praktek penggunaan alat pres ulir yang dilakukan bersama-sama dengan pengrajin tahu dengan arahan dari tim pengabdian kepada masyarakat. Dalam proses ini peserta terlibat langsung secara aktif melakukan proses praktek pengepresan tahu dengan alat yang dikenalkan oleh tim pengabdian kepada masyarakat. Hasil dari praktek ini adalah sangat menyingkat waktu pengepresan yang hanya memakan waktu kurang lebih 5 menit dibandingkan pengepresan secara manual yang memakan waktu tidak kurang dari 30 menit.

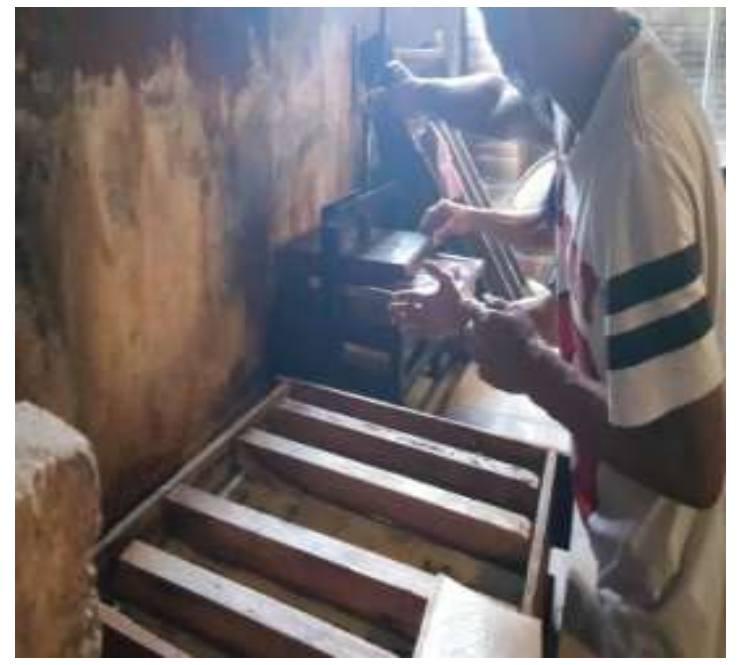

Gambar 8. Pengepresan tahu menggunakan alat pres ulir

Dari kegiatan praktek penggunaan alat pengepresan sistem ulir ini peserta merasakan kelebihan menggunakan metode ini yang secara langsung adalah menyingkat waktu proses pengepresan, serta tenaga yang dibutuhkan jauh berkurang karena yang pengepresan secara manual harus mengangkat beban penindih berupa 3 buah beton cor seberat masing-masing sekitar $15 \mathrm{~kg}$. Dengan menggunakan alat ini, operator hanya perlu memutar tuas dengan ringan untuk melakukan penekan pada tahu yang siap dipres.

\section{Faktor Pendorong}

Kesediaan dan kesiapan kelompok pengrajin tahu "Maju Bersama" di Gerisak Kelurahan Kekalik Jaya Kota Mataram untuk menerima kegiatan pengabdian kepada masyarakat ini merupakan faktor 
penting. Persiapan sarana dan prasarana pelatihan sangat membantu terlaksananya penyuluhan ini. Selain itu partisipasi dan antusiasme peserta dalam mengikuti kegiatan penyuluhan sangat baik, merupakan faktor pendorong dalam pelaksanaan penyuluhan.

\section{Faktor Penghambat}

Selama kegiatan penyuluhan ditemukan sedikit penghambat yaitu ketersediaan waktu pengrajin untuk terselenggaranya kegiatan karena setiap hari mereka melakukan produksi. Namun dengan memanfaatkan waktu yang ada di sela kegiatan mereka, kegiatan ini dapat terselenggara dengan lancar.

\section{Evaluasi}

Berdasarkan hasil pengamatan pada saat pelaksanaan penyuluhan berlangsung serta kesan yang diberikan oleh peserta penyuluhan, maka dapat dievaluasi sebagai berikut, pengrajin tahu peserta penyuluhan berharap mendapatkan bantuan alat dalam jumlah memadai untuk membantu proses produksi mereka, dalam hal ini adalah alat pres ulir yang akan bermanfaat dalam proses pengepresan tahu mereka.

$$
\text { Peserta kegiatan begitu }
$$

bersemangat dalam mengikuti penyuluhan, hal ini dapat diamati dengan partisipasi dan antusiasme peserta dalam mengikuti kegiatan penyuluhan sangat baik mulai dari awal pelatihan sampai akhir. Materi penyuluhan sudah cukup sesuai, relevan serta bermanfaat bagi masyarakat sasaran kegiatan.

\section{KESIMPULAN DAN SARAN}

\section{Kesimpulan}

Kesimpulan dari pelaksanaan kegiatan pengabdian kepada masyarakat ini adalah:
1. Keseluruhan program pengabdian kepada masyarakat dengan topik "Metode Pengepresan Untuk Meningkatkan Kepadatan Tahu pada Industri Tahu Kelurahan Kekalik Jaya Kota Mataram" telah dilakukan dengan lancar. Dari hasil kegiatan yang dilakukan masyarakat pengrajin tahu telah memahami aspek pentingnya penerapan peralatan mekanis.

2. Peserta kegiatan begitu bersemangat dalam mengikuti penyuluhan, hal ini dapat diamati dengan partisipasi dan antusiasme peserta dalam mengikuti kegiatan penyuluhan sangat baik mulai dari awal pelatihan sampai akhir.

3. Materi penyuluhan sudah cukup sesuai, relevan serta bermanfaat bagi masyarakat

4. Kebutuhan alat mekanis dalam proses pengepresan tahu diperlukan untuk menciptakan keamanan dan kenyamanan kerja, menyingkat waktu proses, dan meningkatkan kualitas kepadatan tahu.

\section{Saran}

Setelah dilakukannya kegiatan pengabdian kepada masyarakat ini perlu dilakukan evaluasi, yaitu mengenai perlu adanya bantuan penyediaan alat serupa untuk membantu proses pengepresan tahu di kawasan pengrajin tahu Kelurahan Kekalik Jaya Kota Mataram.

\section{UCAPAN TERIMA KASIH}

Untuk terselenggaranya kegiatan ini disampaikan terimakasih atas dukungan biaya dari DIPA BLU Universitas Mataram Tahun Anggaran 2018, dengan surat perjanjian nomor: 1042/UN18/LPPM/2018 tanggal 10 April 2018

\section{DAFTAR PUSTAKA}

Pratomo, M.C., 2019. Perancangan Leadscrew pada alat tambal ban 
press. https://www.academia.edu /8479157. Diakses 28 Maret 2019.

Rukmana, H., 2018. Analisis Ergonomi terhadap Operator Mesin Penggiling pada tipe Two Pass dengan Pendekatan Biomekanika dan Antropometri. Skripsi. Fakultas Teknologi Pangan dan Agroindustri Universitas Mataram, Mataram.
Suharto, 1991. Teknologi Pengawetan Pangan. PT. Rineka Cipta, Jakarta.

Suprapti, L., 2005. Pembuatan Tahu. Penerbit Kanisius. Yogyakarta.

Taib, G., 1988. Operasi Pengeringan Pada Pengolahan Hasil Pertanian. PT. Mediyatama Sarana Perkasa. Jakarta. 